\title{
SILKY RINGLET EREBIA GORGE VAGANA (LEPIDOPTERA: NYMPHALIDAE) STILL SURVIVING ON VELEBIT
}

\author{
Rudi VerovniK \\ University of Ljubljana, Biotechnical Faculty, Department of Biology, Jamnikarjeva 101, \\ 1000 Ljubljana, Slovenia (rudi.verovnik@bf.uni-lj.si)
}

Verovnik, R.: Silky Ringlet Erebia gorge vagana (Lepidoptera: Nymphalidae) still surviving on Velebit. Nat. Croat., Vol. 24, No. 1, 159-162, 2015, Zagreb.

After more than 70 years the endemic subspecies of Silky Ringlet Erebia gorge vagana was again observed at the type locality near Vaganski vrh on Mt Velebit, Croatia. At least four adults were seen on north-facing screes in August 2014. As it is limited to the highest parts of the mountain, the species is severely threatened by current climate change and long term monitoring of this isolated population would be of great scientific importance.

Key words: butterflies, alpine belt, climate change, distribution

Verovnik, R.: Velebitski planinski okaš Erebia gorge vagana (Lepidoptera: Nymphalidae) još uvijek prisutan na Velebitu. Nat. Croat., Vol. 24, No. 1, 159-162, 2015, Zagreb

Nakon više od 70 godina endemska podvrsta velebitski planinski okaš Erebia gorge vagana ponovno je pronađena na tipskom lokalitetu blizu Vaganskog vrha na Velebitu, Hrvatska. Na sjeverno eksponiranom točilu u kolovozu 2014. bile su opažene najmanje četiri jedinke. S obzirom da je vrsta ograničena na najviše dijelove planine, trenutne klimatske promjene predstavljaju ozbiljnu prijetnju, pa bi dugoročno praćenje te izolirane populacije bilo od velike znanstvene važnosti.

Ključne riječi: danji leptiri, alpski pojas, klimatske promjene, rasprostranjenost

The famous Croatian lepidopterist Zdravko Lorković first reported a surprising discovery of a high alpine butterfly Erebia gorge (Hübner, 1804) on Velebit in 1937 in a paper dealing with the question of the highest peak of this mountain range. He found the butterflies on a scree in a small gully on the north-facing slopes just below the highest peak of Mt Velebit, Vaganski vrh, in the year 1924 (Lorković, 1937). Subsequently, he also observed the species on nearby Babin vrh, again on steep screes on north-facing slopes at altitudes between 1600 and 1700 m (Lorković, 1955). Due to the consistant differences in wing patterns compared to nearby populations in Bosnia and Slovenia he described the new subspecies as E. gorge vagana Lorković, 1955 . The butterfly was last seen on Velebit in 1940 (Mladinov \& Lorković, 1985).

Although the butterflies of Velebit have been studied in recent years, no additional finds of the species have been reported. However, the authors explicitly state that localities with E. gorge vagana were not visited (Kučınıć et al., 1995; Мıнос et al., 2007). The region with the highest peaks in southern Velebit was inaccessible for some time due to mine fields laid during the conflicts in the 1990s. Currently, all the major mountain paths in the region have been cleared of mines and access to Vaganski vrh from the north side from Lika is easy. 


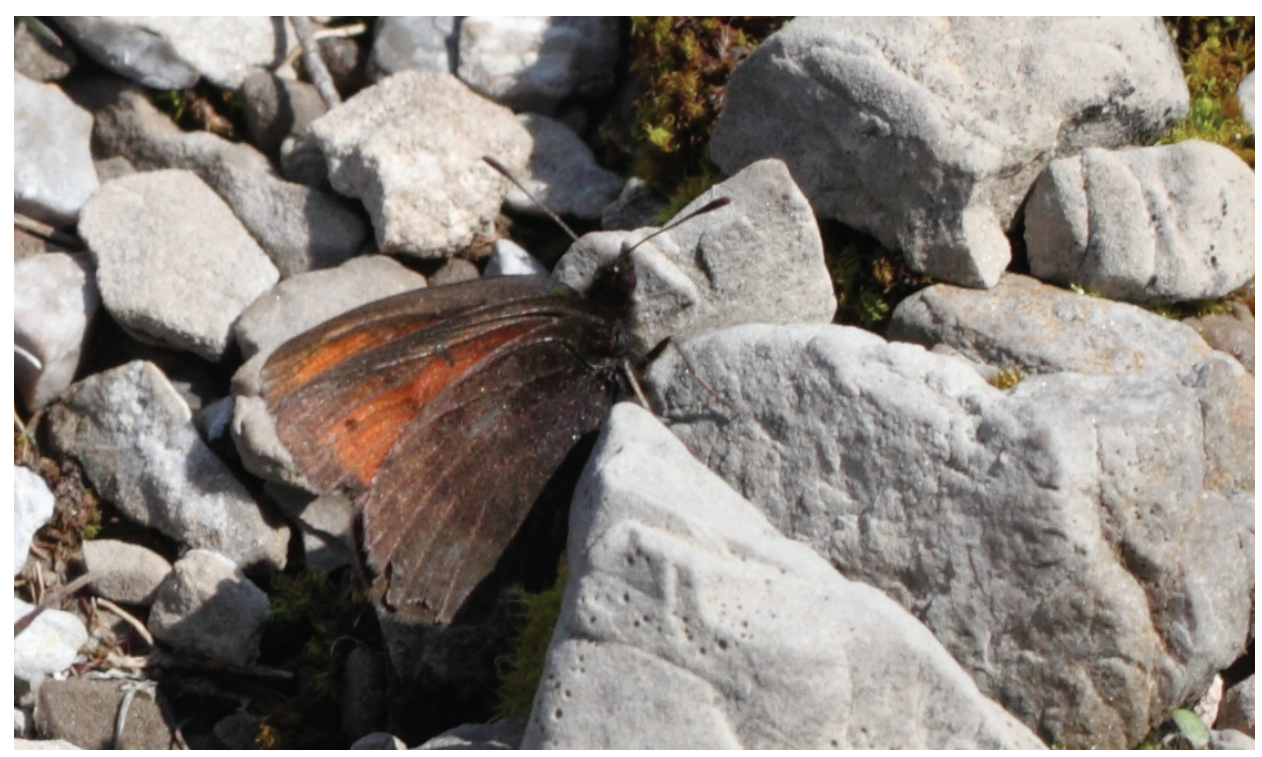

Fig. 1. A worn male of Erebia gorge vagana perched on the gravel at Vaganski vrh on 12.8.2014.

On August 12, 2014 I climbed Vaganski vrh using the mentioned route from the north side with one major objective: to check if E. gorge vagana was still present. Given the recent climatic changes its contiguous presence on Velebit could not be taken for granted. It did not take long to recognise the locality where Lorković made his observations of E. gorge vagana given his detailed description of the habitat (LoRKOvić, 1955). Just north of Vaganski vrh the path crosses a small partially overgrown scree on the north-facing slope that still looks suitable for this petrophilous species. Once at the site, some patience was required to check all the passing Erebia butterflies to recognise finally that E. gorge vagana was still among them. During half an hour possibly four different specimens (1 male, 3 females) were observed, all past their prime in a rather tatty condition indicating the end of their flight period. They were extremely shy and also not easy to approach because of the steep terrain therefore just photographs from a distance were made for the record (Fig. 1). On that day, the site was sheltered from the wind so many other butterfly species were present. Among Erebia, three additional species were observed. The most common was E. melas (Herbst, 1796), while E. ottomana Herrich-Schäffer, 1847 was dominant on nearby grassy slopes and the peak of Vaganski vrh. A single worn female of E. oeme (Hübner, 1804) was seen there as well. Additionally, Gonepteryx rhamni (Linnaeus, 1758), Colias croceus (Fourcroy, 1785), Polyommatus coridon (Poda, 1761), Polyommatus eros (Ochsenheimer, [1808]), Argynnis aglaja (Linnaeus, 1758), Argynnis pandora ([Denis \& Schiffermüller], 1775), Aglais urticae (Linnaeus, 1758), Vanessa cardui (Linnaeus, 1758), Melanargia galathea (Linnaeus, 1758), Coenonympha rhodopensis Elwes, 1900, and Hipparchia semele (Linnaeus, 1758) were seen at the site. Among these a single female of P. eros was the only siginificant find, as it was not reported in recent surveys on Velebit (Kučinić et al., 1995; Miнoci et al., 2007). En route, some other species were also observed, but only an egg-laying female of Carcharodus lavatherae (Esper, [1783]) above the depression Cesaričina dolina at $1560 \mathrm{~m}$ is worth mentioning. 
E. gorge vagana is considered threatened (EN) in Croatia due to the small area of occupancy, severe fragmentation and projected continuous decline (ŠAšIć \& KučInIĆ, 2004). It is also a strictly protected species and all known populations are within one of the national parks in Croatia. The major concern for the species is the current trend of climate change as with raising temperatures the species cannot retreat to higher elevations as it is already limited to the highest parts of Mt Velebit. As suggested by Lorкоvić (1955), its presence on the peaks of Velebit indicates that from the end of the last glacial period there were no big climatic oscillations which would certainly have caused the extinction of this geographically extremely limited population of E. gorge. The current climatic changes are known to modify the ranges of several butterfly species (PARMESAN et al., 1999) and severe range contractions of high alpine species in southern Europe are predicted (SETtele et al., 2008). It remains to be seen if E. gorge vagana will survive the next century in which temperatures will rise and its habitats become overgrown. Despite the lower altitude, the screes below the rocky northern faces of Vaganski vrh, which are more shaded, could provide an additional refuge for the species, but this will be hard to check due to the inaccessibility of this habitat. Certainly, in the Julian Alps the species is known to be sporadically found at altitudes down to $1300 \mathrm{~m}$ on shaded screes with dwarf pine (Verovnik et al., 2012), so there is hope the same is true of Velebit. Regular monitoring of this isolated population of E. gorge would be of high scientific and conservation importance.

Received February 23, 2015

\section{REFERENCES}

Kučinić, M., Baltić, M. \& Matešıć, M., 1995: Danji leptiri (Insecta, Lepidoptera, Rhopalocera) Velebita: faunističke i zoogeografske karakteristike. Paklenički zbornik 1, 169-188.

Lorković, Z., 1937: Najviši vrh Velebita. Hrvatski planinar 33 (11), 331-337.

Lorković, Z., 1955: Die Populationsanalyse zweier neuen stenochoren Erebia-Rassen aus Kroatien. Biološki glasnik 8, 53-76.

Mıносı, I., ŠAšić, M. \& Vuković, M., 2007: Contribution to the butterfly fauna (Hesperioidea \& Papilionoidea) of theVelebit Mountain, Croatia. Natura Croatica 16 (1), $29-62$.

Mladinov, L. \& Lorković, Z. 1985: Rasprostranjenje montanih Macrolepidoptera u fauni SR Jugoslavije. Acta Ent. Jug. 21 (1-2), 17-36.

Parmesan, C., Ryrholm, N., Stefanescu, C., Hill, J. K., Thomas, C. D., Descimon, H., Huntley, B., Kaila, L., Kullberg, J., Tammaru, T., Tennent, W. J., Thomas, J. A. \& Warren, M., 1999: Poleward shifts in geographical ranges of butterfly species associated with regional warming. Nature 399, 579-583.

ŠAšıć, M. \& Kučinić, M., 2004: The Red Data List of Croatian butterflies. In Marković, D. (ed.). State Institute for Nature Protection.

Settele, J., Kudrna, O., Harpke, A., Kuehn, I., Van Swaay, C., Verovnik, R., Warren, M., Wiemers, M., Hanspach, J., Hickler, T., Kühn, E., Van Halder, I., Veling, K., Vliegenthart, A., Wynhoff, I. \& Schweiger, O., 2008: Climatic Risk Atlas of European Butterflies. BioRisk 1, 659 pp.

Verovnik, R., Rebeušek, F. \& Jež, M., 2012: Atlas of butterflies (Lepidoptera: Rhopalocera) of Slovenia. Center za kartografijo favne in flore, Miklavž na Dravskem polju, 456 pp. 


\title{
SAŽETAK
}

\section{Velebitski planinski okaš Erebia gorge vagana (Lepidoptera: Nymphali- dae) još uvijek prisutan na Velebitu}

\author{
R. Verovnik
}

Velebitski planinski okaš Erebia gorge vagana je endemska podvrsta koju je na Velebitu prvi pronašao poznati hrvatski lepidopterolog Zdravko Lorković 1924. godine. Njezina distribucija je ograničena na najviše dijelove Velebita, između Vaganskog i Babinog vrha. U tom dijelu vrsta je vezana na točila sa sjevernom ekspozicijom. Vrsta je posljednji put bila nađena 1940. godine.

Ponovni nalaz Velebitskog planinskog okaša na Velebitu bio je upitan zbog klimatskih promjena, s obzirom da vrsta nema viših nadmorskih razina na kojima bi mogla izbjeći dizanje temperature. Ipak, na tipskom lokalitetu pored Vaganskog vrha u kolovozu 2014. na točilu sjeverne ekspozicije bile su zapažene najmanje četiri jedinke. Vrsta je u Hrvatskoj ugrožena (EN) najviše zbog utjecaja klimatskih promjena, i zato je dugoročni monitoring ove izolirane populacije od velike znanstvene važnosti. 